\title{
PENGUJIAN PUPUK HANTU TERHADAP PERKECAMBAHAN BENIH SELADA (Lactuca sativa, L)
}

\author{
Oleh: Surtinah \\ Staf Pengajar Fakultas Pertanian Universitas Lancang Kuning
}

\begin{abstract}
ABSTRAK
Penelitian Ini bertujuan untuk menguji pupuk hantu dalam menstimulir perkecambahan benih selada. Rancangan lingkunan yang digunakan adalah Rancangan Acak Lengkap, dan uji statistik yang digunakan adalah Uji t Berpasangan pada taraf uji $1 \%$. Parameter yang diamati adalah viabilitas benih selada, Kecepatan perkecambahan benih selada, Tinggi bibit selada pada waktu pindah tanam, dan waktu pindah tanam. Hasil penelitian menunjukkan bahwa perlakuan pupuk hantu memberikan beda yang sngat nyata terhadap viabilitas benih, kecepatan perkecambahan, tinggi bibit, dan waktu pindah tanam bibit selada.
\end{abstract}

Kata Kunci: Benih selada, viabilitas, perkecambahan, bibit selada.

\section{PENDAHULUAN}

Tanaman selada ( Lactuca sativa, $\mathrm{L}$ ), merupakan tanaman sayuran semusim, yang termasuk dalam famili Compositae. Selada biasanya disajikan sebagai sayuran penyegar. Adapun kandungan vitamin yang terdapat di dalam daun selada diantaranya: vitamin $\mathrm{A}$, vitamin $\mathrm{B}$, vitamin $\mathrm{C}$ yang sangat berguna untuk kesehatan tubuh (Pracaya, 2007). Selain itu tanaman selada memiliki nilai ekonomi yang tinggi dan digemari.

Kebutuhan selada untuk Kota Pekanbaru belum dapat dipenuhi oleh petani tempatan, oleh karena dalam membudidayakan selada banyak kendala yang harus dihadapi oleh petani, salah satunya adalah masalah persemaian benih.

Selada dikembangbiakan dengan bijinya, namun persentase perkecambahan benih selada berkisar antara $40 \%$ - $75 \%$. Hal ini yang menyebabkan petani kurang berminat untuk membudidayakan selada. Di lapangan ditemukan bahwa perkecambahan benih selada tidak sampai $50 \%$. Hasil yang tidak sebanding dengan harga benih, dan biaya pemeliharaan persemaian, ini merupakan masalah yang dihadapi oleh petani selada. Oleh karena itu perlu dicari suatu solusi untuk meningkatkan viabilitas benih selada, agar petani tidak mengalami kerugian dalam proses budidaya selada tersebut. Selain persentase perkecambahan yang rendah, waktu yang dibutuhkan untuk proses perkecambahan benih juga lama.

Benih-benih yang mengalami keterlambatan dalam berkecambah dapat dipacu perkecambahannya dengan perlakuan-perlakuan tertentu, seperti merendam benih dalam suatu larutan yang mengandung unsurunsur hara dan zat pengatur tumbuh. Dengan pemberian perlakuan tersebut diharapkan benih-benih yang memiliki viabilitas yang rendah dapat ditingkatkan viabilitasnya.

Pupuk Hormon tanaman Unggul (Hantu) merupakan salah satu pupuk yang mengandung unsur hara makro dan mikro, juga mengandung zat pengatur tumbuh yang dapat meningkatkan perkecambahan benih dan 
pertumbuhan kecambah sampai menjadi bibit yang siap untuk dipindahkan ke lapangan.

Proses perkecambahan suatu benih diawali dengan imbibisi, bila cairan yang diserap oleh benih pada waktu imbibisi mengandung unsurunsur yang dapat digunakan untuk pertumbuhan tanaman, maka kecambah yang muncul akan memiliki viabilitas yang tinggi, karena kebutuhan unsur hara dalam proses perkecambahan selain diperoleh dari benih juga diperoleh dari bahan yang diberikan. Hormon yang terkandung dalam pupuk Hantu sangat berperan dalam proses perkecambahan, seperti Giberellin, Sitokinin, dan Auksin.

Pada proses perkecambahan benih ketiga hormon ini berperan dalam meningkatkan kerja enzim dalam perombakan bahan makanan yang terkandung di dalam biji. Oleh karena itu diharapkan dengan memperlakukan benih selada dengan pupuk hantu akan mempercepat proses perkecambahannya, dan dapat meningkatkan viabilitasnya, juga mempercepat waktu yang dibutuhkan untuk pindah tanam.

Benih Selada berukuran kecil, lonjong, pipih (gepeng), dan berbulu tajam. Sebelum disemai benih direndam terlebih dahulu untuk meningkatkan viabilitasnya, selama 15 menit, ditiriskan, dan benih disebar dalam alur dengan jarak antar alur $10 \quad$ x $20 \quad \mathrm{~cm}$ (Anonim, 2007).

Media semai yang digunakan adalah campuran tanah dengan pupuk kandang dengan perbandingan $2: 1$, keasaman tanah yang dikehendaki adalah $5.0-6,8$. Persemaian diberi naungan agar kelembaban terjaga. Bibit dipelihara secara intensif dan disiram setiap hari dengan siraman halus (Anonim,2009).
Media tanam yang paling baik berdasarkan laporan penelitian yang dilakukan oleh Mulyani, Rosadi, dan Tusi (2008) adalah selada yang ditanam dengan menggunakan media pasir, yang menghasilkan tinggi tanaman 14,21 $\mathrm{cm}$, jumlah daun 7,10 helai,indeks luas daun 294,53 $\mathrm{cm}^{2}$, berat berangkasan basah 6757,13 mg, dan berat berangkasan kering 509,50 mg.

Faktor yang mempengaruhi perkecambahan benih ada dua yaitu faktor dari luar dan faktor dari dalam benih itu sendiri. Faktor luar yang mempengaruhi perkecambahan benih adalah: (1) Air, (2) Oksigen, (3) Cahaya, (4) Suhu ( Kamil, 2005).

Air memegang peranan penting pada proses perkecmbahan, dimana pada awal perkecambahan tersebut kebutuhan air meningkat. Peranan air pada proses perkecambahan adalah untuk melunakkan kulit benih, untuk pelarut, sebagai pereaksi, untuk kegiatan metabolisme, dan untuk transportasi (Sutopo,2004).

Bila air yang diserap oleh benih mengandung unsur hara, maka benih secara tidak langsung akan mendapatkan stimulan dalam proses perkecambahannya. Dengan masuknya air ke dalam benih maka otomatis hara yang terkandung di dalam larutan juga ikut masuk, dengan catatan bahwa konsentrasi air masih dalam batas yang dapat ditolerir oleh benih. Karena air yang dapat diserap oleh benih adalah air yang konsentrasinya lebih rendah dibandingkan konsentrasi cairan yang ada di dalam benih (Kamil, 2005).

Hantu merupakan pupuk yang mengandung unsur hara $\mathrm{N} 6.3$ $\%$, P $6 \%$, K $14 \%$, Na $0.22 \%$, Cu $0.05 \%$, Fe $0.68 \%$, Mn $0.02 \%, \mathrm{Zn}$ $0.01 \%, \mathrm{Cd}<0.01 \%, \mathrm{~Pb} 0.21 \mathrm{ppm}$. Selain itu hantu juga mengandung 
GA3 98.37 ppm, GA5 107.08 ppm,GA7 131.46 ppm, Auxin IAA $56.35 \mathrm{ppm}$, dan Sitokinin (Kinetin 128.04 ppm, dan Zeatin 106.45 ppm) (Anonimous, 2007).

Gibberellin sebagai hormon tumbuh pada tanaman sangat berpengaruh pada sifat genetik, pembuangan, penyinaran, partohenocarpy, mobilisasi karbohidrat selama perkecambahan dan aspek fisiologi kainnya. Gibberelline mempunyai peranan dalam mendukung perpanjangan sel (cell elongation), aktivitas kambium dan mendukung pembentukan RNA baru serta sintesa protein. Mobilisasi bahan makanan selama fase perkecambahan (germination). Biji serealia terdiri dari embrio dan endosperm. Didalam endosperm terdapat masa pati (starch) yang dikelilingi oleh suatu lapisan "aleuron".. sedangkan embrio itu sendiri merupakan suatu bagian hidup yang suatu saat akan menjadi dewasa. Pertumbuhan embrio selama perkecambahan bergantung pada persiapan bahan makanan yang berada di dalam endosperm. Untuk keperluan kelangsungan hidup embrio maka terjadilah penguraian secara enzimatik yaitu terjadi perubahan pati menjadi gula yang selanjutnya ditranslokasikan ke embrio sebagai sumber energi untuk pertumbuhannya (Anonimous, 2008 dalam Surtinah, 2010).

Penelitian pertumbuhan pith tissue culture dengan menggunakan cytokinin dan auxin dalam berbagai perbandingan telah dilakukan oleh Weier et al (1974). Dihasilkan bahwa

\section{METODE PENELITIAN}

Penelitian ini dilakukan secara eksperimen dengan memberi perlakuan kepada benih selada. Perlakuan yang diberikan adalah perendaman benih selada selama 15 menit dengan menggunakan: apabila dalam perbandingan cytokinin lebih besar dari auxin, maka hal ini akan memperlihatkan stimulasi pertumbuhan tunas dan daun. Sebaliknya apabila cytokinin lebih rendah dari auxin, maka ini akan mengakibatkan stimulasi pada pertumbuhan akar. Sedangkan apabila perbandingan cytokinin dan auxin berimbang, maka pertumbuhan tunas, daun dan akar akan berimbang pula. Tetapi apabila konsentrasi cytokinin itu sedang dan konsentrasi auxin rendah, maka keadaan pertumbuhan tobacco pith culture tersebut akan berbentuk callus. Sedangkan dalam pembelahan sel, dikemukakan bahwa IAA dan kinetin, apabila digunakan secara tersendiri akan menstimulasi sintesis DNA dalam tobacco pith culture. Dan menurut ahli tsb, kehadiran IAA dan kinetin ini diperlukan dalam proses mitosis walaupun IAA lebih dominan pada fase tersebut. Interaksi Cytokinin, Gibberellin dan Auxin dalam perkembangan tanaman. Di dalam alam tidak satu unsurpun yang berdiri sendiri. Kesemuanya berinteraksi antara satu sama lainnya, sehingga merupakan suatu sistem. Begitu pula dengan zat pengatur tumbuh. Pada tanaman, zat pengatur tumbuh auxin, gibberellin dan cytokinin bekerja tidak sendirisendiri, tetapi ketiga hormon tersebut bekerja secara berinteraksi yang dicirikan dalam perkembangan tanaman ( Fiona, 2008). Tujuan penelitian adalah untuk menguji pupuk hantu dalam menstimulir perkecambahan benih selada.

\section{Rancangan Penelitian}

$$
\begin{aligned}
\mathrm{a}_{1}= & \begin{array}{c}
\text { perendaman dalam air murni }( \\
\text { aquadest })
\end{array} \\
\mathrm{a}_{2}= & \begin{array}{c}
\text { perendaman } \\
\text { menggunakan Hara }
\end{array} \\
& \begin{array}{r}
\text { dengan } \\
\text { Unggulan (Hantu) } \\
\text { konsentrasi } 0.2 \% .
\end{array}
\end{aligned}
$$


Benih yang sudah direndam, ditiriskan di atas tisue, setelah tiris airnya benih ditanam di dalam pot yang sudah disediakan. Jumlah ulangan setiap perlakuan 15,

\section{Analisis Data}

Data yang diperoleh dianalisa dengan menggunakan Uji-t berpasangan, bila t Hitung lebih kecil bila dibandingkan dengan $t$ Tabel maka disimpulkan bahwa perendaman yang dilakukan dengan menggunakan dua jenis larutan tidak berbeda nyata, namun bila $t$ hitung lebih besar bila dibandingkan dengan $\mathrm{t}$ Tabel maka perlakuan yang dilakukan tersebut berbeda nyata.

\section{Perlakuan benih}

Pada perlakuan pertama benih direndam dengan larutan

hantu $0.2 \%$ selama 15 menit, kemudian ditiriskan.

Perlakuan kedua, benih direndam dengan air murni selama 15 menit, kemudian ditiriskan.

\section{Persemaian}

Benih yang sudah ditiriskan, ditanam di lubang tanam yang dibuat secara larikan dengan jarak $10 \mathrm{~cm}$. antar larikan, kemudian disiram perlahan-lahan.

\section{Pemeliharaan}

Benih yang sudah ditanam disiram setiap hari dengan menggunakan hand sprayer dengan pemberian air yang sama untuk setiap unit percobaan.

\section{Pencegahan Penyakit dan Hama}

Pencegahan penyakit bibit dilakukan dengan menggunakan Dithane-45 dengan dosis $2 \mathrm{~g} / 1$ air, pada saat kecambah berumur 10 hari, sehingga diperoleh jumlah unit percobaan $=30$ unit. Setiap unitnya ditanami benih sebanyak 50 butir.

\section{Pelaksanaan Penelitian Persiapan media}

Media persemaian terdiri dari campuran tanah dan pupuk kandang dengan perbandingan $2: 1$. Tanah dibersihkan dan diayak, kemudian dicampur pupuk kandang yang sudah siap pakai, lalu dimasukkan kedalam wadah dengan berat $1 \mathrm{Kg}$.

dengan interval waktu pemberian 10 hari.

Pencegahan Hama dilakukan dengan menggunakan Bayrusil 250 EC dengan konsentrasi $2 \mathrm{ml} / \mathrm{l}$ air. Dilakukan penyemprtan 1 minggu sekali.

\section{Parameter Pengamatan}

1. Viabilitas benih

Dilakukan pengamatan terhadap jumlah benih yang berkecambah dalam waktu 1 minggu sejak semai.

2. Kecepatan berkecambah

Kecepatan berkecambah didapat dengan menghitung jumlah kecambah yang muncul dibagi tujuh hari.

3. Tinggi bibit Mengukur tinggi bibit yang siap dipindahkan ke lapangan.

4. Waktu pindah tanam Menghitung jumlah hari dari saat semai sampai bibit siap pindah tanam (daun 4 helai). 


\section{HASIL DAN PEMBAHASAN}

\section{Hasil Penelitian}

Hasil pengamatan dari pengujian pupuk hantu terhadap viabilitas benih selada ditampilkan pada tabel-tabel hasil pengamatan di bawah ini.

\section{Viabilitas benih}

Tabel 1. Viabilitas Benih Selada Pada Umur 7 hari setelah semai (\%)

\begin{tabular}{|c|c|c|}
\hline NO. & Dengan Pupuk Hantu & Tanpa Pupuk Hantu \\
\hline 1. & 90 & 90 \\
\hline 2. & 86 & 92 \\
\hline 3. & 82 & 84 \\
\hline 4. & 90 & 90 \\
\hline 5. & 100 & 82 \\
\hline 6. & 100 & 88 \\
\hline 7. & 100 & 86 \\
\hline 8. & 98 & 80 \\
\hline 9. & 100 & 84 \\
\hline 10. & 92 & 84 \\
\hline 11. & 94 & 90 \\
\hline 12. & 90 & 80 \\
\hline 13. & 100 & 84 \\
\hline 14. & 90 & 90 \\
\hline 15. & 100 & 90 \\
\hline T hitung $=3.81 ; \mathrm{t}$ Tabel $1 \%=2.977$ & \\
\hline
\end{tabular}

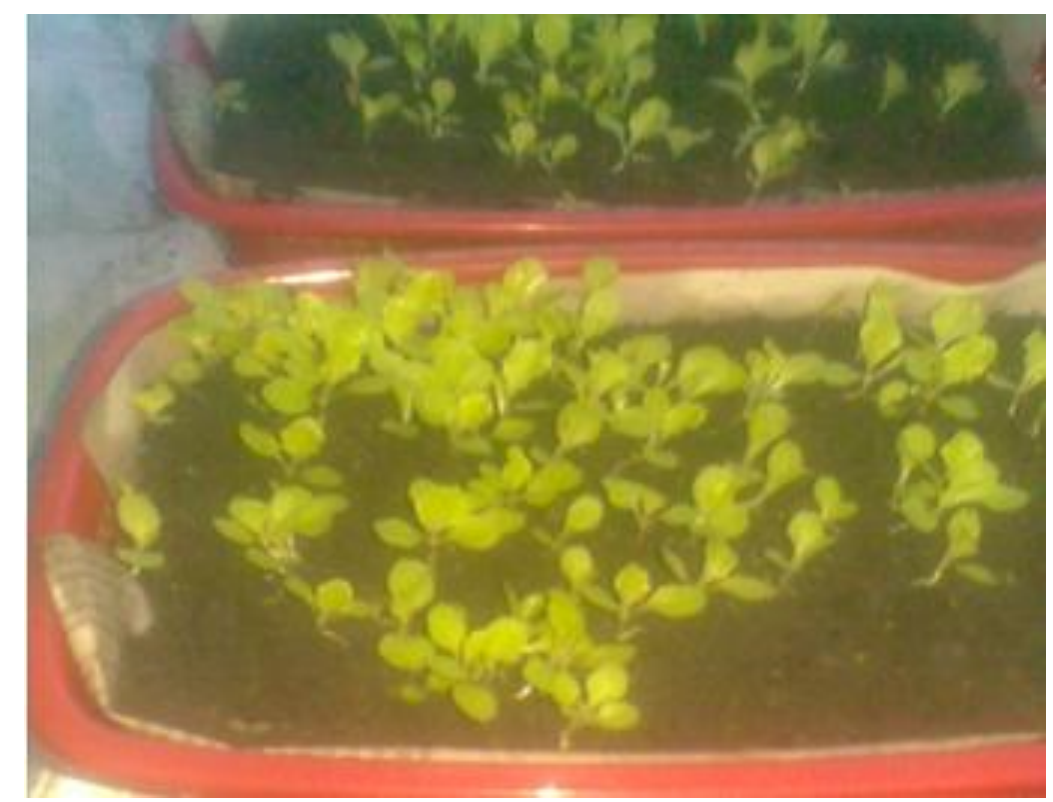

Gambar 1. Kecambah selada pada umur 7 hari setelah semai pada perendaman biji dengan pupuk hantu selama 15 menit. 


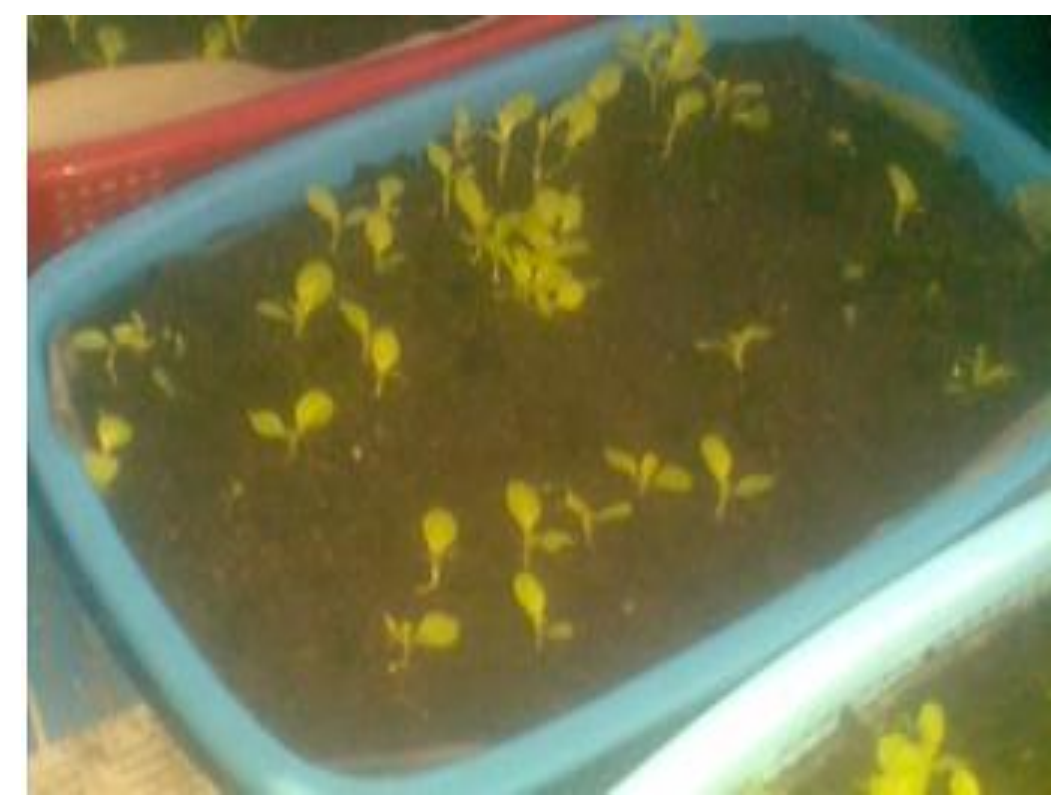

Gambar 2. Kecambah selada pada umur 7 hari setelah semai pada perendaman biji dengan air murni selama 15 menit.

\section{Kecepatan berkecambah (kecambah/hari)}

Tabel 2. Kecepatan berkecambah benih selada (kecambah/hari)

\begin{tabular}{|c|c|c|}
\hline NO. & Dengan Pupuk Hantu & Tanpa Pupuk Hantu \\
\hline 1. & 6.43 & 6.43 \\
\hline 2. & 6.14 & 6.57 \\
\hline 3. & 5.86 & 6.00 \\
\hline 4. & 6.43 & 6.43 \\
\hline 5. & 7.14 & 5.86 \\
\hline 6. & 7.14 & 6.29 \\
\hline 7. & 7.14 & 6.14 \\
\hline 8. & 7.00 & 5.71 \\
\hline 9. & 7.14 & 6.00 \\
\hline 10. & 6.57 & 6.00 \\
\hline 11. & 6.71 & 6.43 \\
\hline 12. & 6.43 & 5.71 \\
\hline 13. & 7.14 & 6.00 \\
\hline 14. & 6.43 & 6.43 \\
\hline 15. & 7.14 & 6.43 \\
\hline T hitung $=3.67 ; \mathrm{t}$ Tabel $1 \%=2.977$ & \\
\hline
\end{tabular}




\section{Tinggi Bibit pada saat pindah tanam $(\mathrm{Cm})$}

Tabel 3. Tinggi bibit selada pada saat pindah tanam dengan kriterian jumlah daun 4 helai

\begin{tabular}{|c|c|c|}
\hline NO. & Dengan Pupuk Hantu & Tanpa Pupuk Hantu \\
\hline 1. & 3.5 & 3.0 \\
\hline 2. & 3.5 & 3.5 \\
\hline 3. & 4.0 & 3.5 \\
\hline 4. & 3.5 & 3.5 \\
\hline 5. & 3.8 & 3.8 \\
\hline 6. & 3.5 & 3.0 \\
\hline 7. & 3.0 & 3.5 \\
\hline 8. & 4.2 & 3.0 \\
\hline 9. & 4.0 & 2.5 \\
\hline 10. & 4.5 & 3.0 \\
\hline 11. & 4.5 & 3.0 \\
\hline 12. & 4.0 & 3.5 \\
\hline 13. & 4.0 & 2.5 \\
\hline 14. & 4.0 & 3.5 \\
\hline 15. & 3.5 & 3.5 \\
\hline T hitung $=3.60 ; \mathrm{t}$ Tabel $1 \%=2.977$ & \\
\hline
\end{tabular}

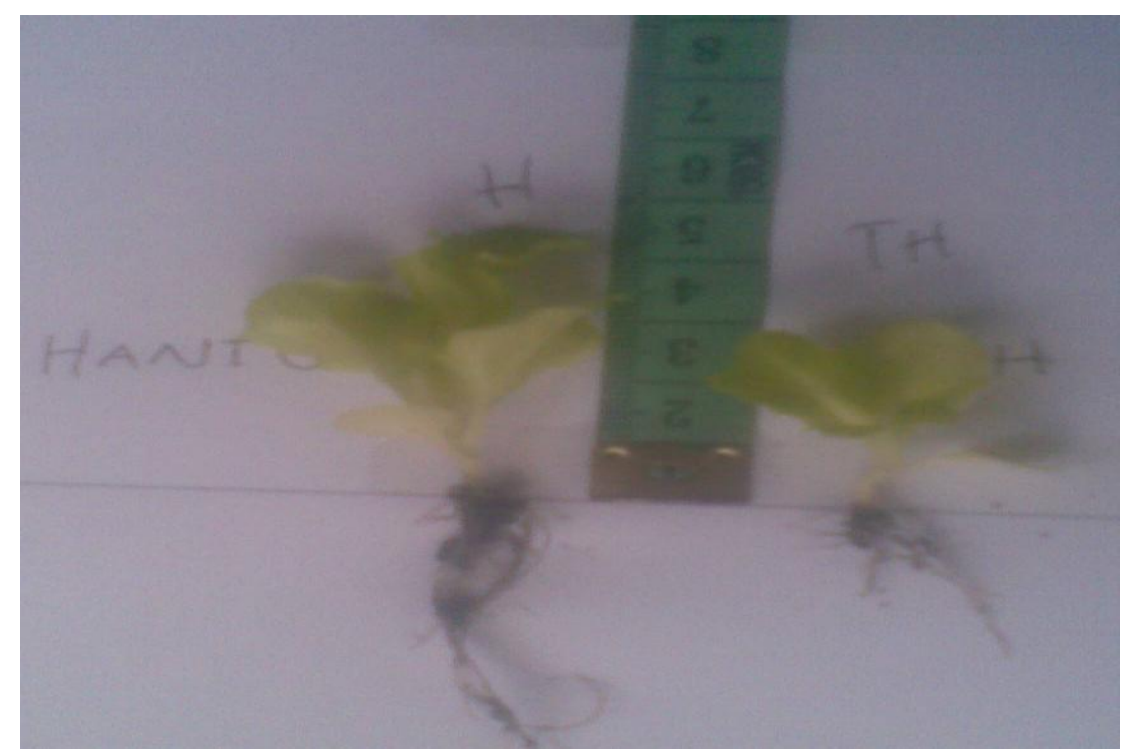

Gambar 3. Sebelah kiri bibit selada dengan perlakuan pupuk hantu, sedangkan sebelah kanan bibit selada dengan perendaman benih dalam air murni, pindah tanam dengan kriteria daun 4 helai. 


\section{Hasil pengamatan waktu pindah tanam (hari)}

Tabel 4. Lamanya waktu yang digunakan untuk pindah tanam (hari)

\begin{tabular}{|c|c|c|}
\hline NO. & Dengan Pupuk Hantu & Tanpa Pupuk Hantu \\
\hline 1. & 28 & 29 \\
\hline 2. & 28 & 29 \\
\hline 3. & 28 & 28 \\
\hline 4. & 28 & 28 \\
\hline 5. & 28 & 28 \\
\hline 6. & 28 & 28 \\
\hline 7. & 28 & 30 \\
\hline 8. & 28 & 30 \\
\hline 9. & 28 & 30 \\
\hline 10. & 28 & 30 \\
\hline 11. & 28 & 31 \\
\hline 12. & 30 & 30 \\
\hline 13. & 31 & 29 \\
\hline 14. & 29 & 30 \\
\hline 15. & 31 & 30 \\
\hline T hitung $=3.00 ;$ t Tabel $1 \%=2.977$ & \\
\hline
\end{tabular}

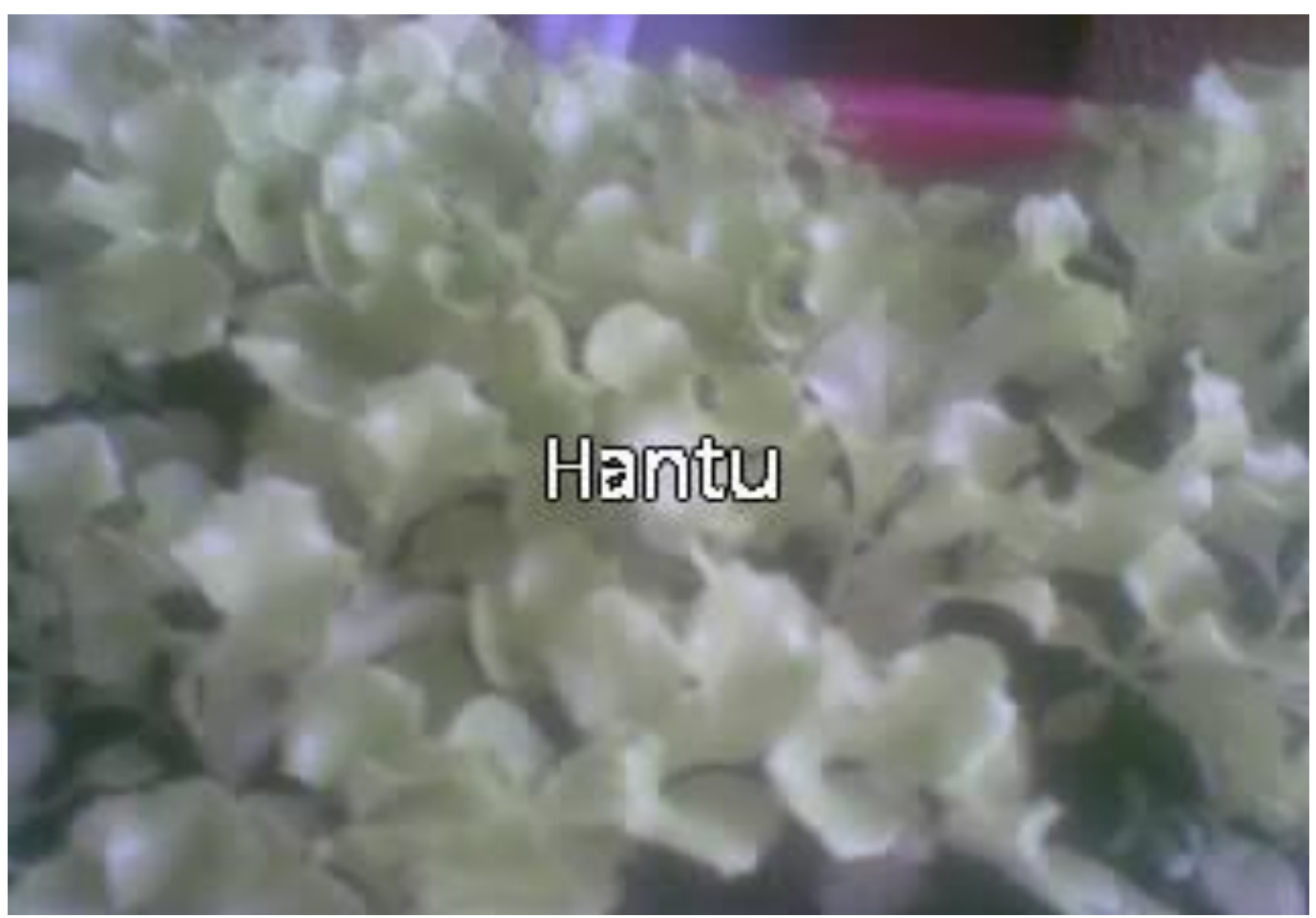

Gambar 4. Bibit selada siap pindah tanam (umur 28 hari) dengan menggunakan pupuk hantu 


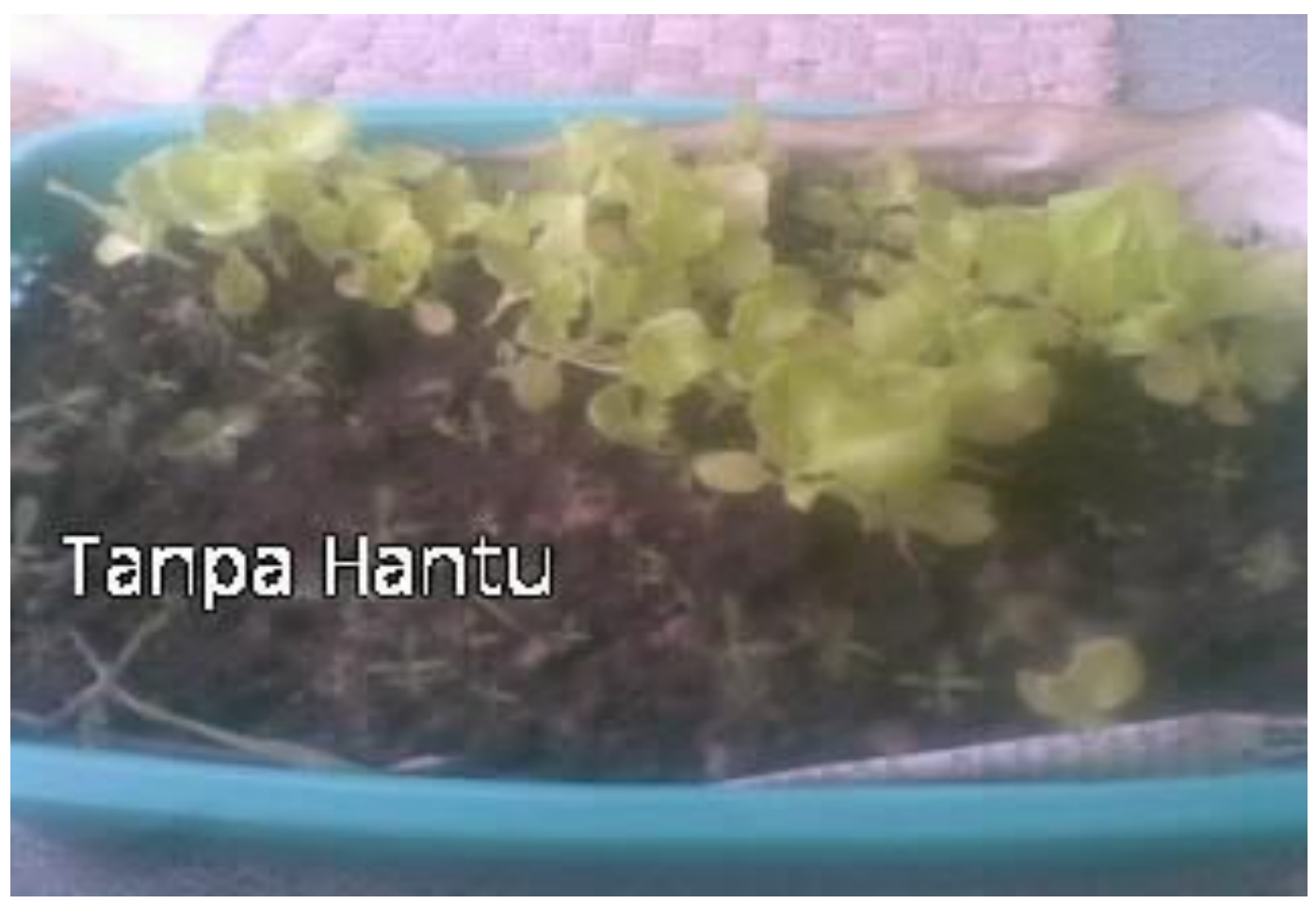

Gambar 5. Bibit selada berdaun 4 helai pada umur 28 hari

\section{Pembahasan}

Pengamatan terhadap semua parameter menghasilkan perbedaan yang sangat nyata antara kedua perlakuan yang dicoba. Viabilitas benih selada, kecepatan perkecambahan benih, tinggi bibit yang siap dipindah tanamkan, dan waktu pindah tanam memperlihatkan keunggulan dari perlakuan pupuk hantu yang diuji coba.

Viabilitas benih selada dan kecepatan berkecambah benih selada yang direndam dengan menggunakan larutan pupuk hantu lebih tinggi dibandingkan dengan viabilitas benih selada yang direndam dengan air murni. Air dalam proses perkecambahan benih sangat diperlukan, karena fungsi air pada proses perkecambahan adalah untuk mengaktifkan enzim-enzim yang akan membantu perkecambahan benih tersebut. Fungsi dari enzim pada proses perkecambahan benih adalah untuk membantu mencerna cadangan makanan yang ada di dalam benih agar dapat dimanfaatkan oleh embrio yang berkecambah menjadi tanaman muda.

Pada proses perkecambahan bila air yang diberikan mengandung zat pengatur tumbuh (zpt), maka zpt tersebut akan dimanfaatkan oleh benih untuk membantu pembentukan sel-sel baru, misalnya auksin dapat meningkatkan sintesis protein, diketahui bahwa protein merupakan bahan yang sangat diperlukan pada proses pertumbuhan dan perkembangan sel. Kehadiran auksin meningkatkan difusi masuknya air ke dalam sel, sehingga proses pencernaan cadangan makanan akan berlangsung sesuai dengan kebutuhan untuk pertumbuhan kecambah. Giberellin yang terkandung dalam pupuk hantu 
berguna untuk meningkatkan kandungan auksin, dan berperan dalam mengaktifkan enzim amilase (Anonimous, 2007 dalam Surtinah, 2010).

$\begin{array}{llr}\text { Pada proses pertumbuhan } \\ \text { embrio menjadi kecambah } \\ \text { tergantung } & \text { dari cadangan makanan } \\ \text { yang ada } & \text { dalam endosperm dan } \\ \text { proses pencernaan cadangan } \\ \text { makanan tersebut. Perombakan }\end{array}$
cadangan makanan dalam endosperm terjadi melalui proses enzimatik, dan hasil perombakan tersebut akan ditranslokasikan ke embrio sebagai sumber energi untuk pertumbuhannya.

Tinggi bibit selada yang siap dipindahkan ke lapangan dan waktu pemindahan bibit, juga berbeda sangat nyata antara benih selada yang diberi pupuk hantu dan benih yang hanya direndam dengan air murni. Hal ini disebabkan karena Giberellin yang terkandung dalam pupuk hantu bekerja dengan baik mempengaruhi perpanjang sel. Seperti yang dinyatakan oleh Setyati (2006), bahwa Giberellin akan menstimulasi pemanjangan sel. Hal ini dapat dijelaskan bahwa aktifnya enzim amilase akan meningkatkan konsentrasi gula dan meningkatnya tekanan osmotik di dalam sel, yang menyebabkan sel tersebut berkembang.

Viabilitas benih, Kecepatan berkecambah, Tinggi bibit, dan waktu pindah tanam yang berbeda sangat nyata antara benih yang direndam pupuk hantu dan benih yang direndam air biasa, juga dipengaruhi oleh hormon Sitokinin yang terkandung di dalam pupuk hantu tersebut. Peranan zat pengatur tumbuh ini adalah pada proses pembelahan sel. Adanya sitokinin di dalam benih akan mengakibatkan pembelahan sel menjadi semakin giat, sehingga akan terbentuk banyak sel baru, dengan adanya unsur hara yang menyertainya, maka kebutuhan untuk memasok bahan kering ke bibit yang sedang tumbuh dapat dipenuhi. Pada bibit yang mendapat perlakuan pupuk hantu kriteria bibit siap dipindahkan ke lapangan lebih cepat terpenuhi dibandingkan dengan bibit yang diberi air murni saja. Menjadi lebih cepat besar sehingga waktu pindah bibit menjadi semakin cepat. Pada tanaman auksin, giberellin, dan sitokinin saling berinteraksi yang dicirikan dalam perkembangan tanaman ( Fiona, 2009).

Anonimous

melaporkan bahwa pupuk hantu merupakan pupuk yang $100 \%$ organik, dan zat pengatur tumbuh yang terkandung dalam pupuk hantu antara lain auksin berperan dalam memperbanyak akar dan tunas akar, giberellin untuk merangsang pembungaan dan pembuahan, zeatin untuk mengurai hara, dan sitokinin/kinetin untuk merangsang pertumbuhan vegetatif organ tanaman secara ekstrim.

Unsur $\mathrm{N}$ yang terkandung dalam pupuk hantu berperan dalam pertumbuhan akar dan daun, sedangkan peranan $\mathrm{P}$ adalah membentuk penyusunan senyawa ATP untuk digunakan pada proses biokimia tanaman seperti transpirasi, fotosintesis, transportasi, dan pembentukan sel. $\mathrm{K}$ berperan dalam mengaktifkan kerja enzim terutama dalam sintesa protein. Mn berperan dalam fotolisis air, $\mathrm{Zn}$ sebagai senyawa awal pembentukan IAA, dan $\mathrm{Cu}$ berperan dalam menyusun plastosianin dan stabilisator klorofil ( Surtinah, 2010 ). 
SIMPULAN DAN SARAN

\section{Simpulan}

1. Pupuk Hantu dapat menstimulir perkecambahan benih selada.

2. Kecepatan perkecambahan benih selada dengan menggunakan pupuk hantu lebih cept dibandingkan dengan yang menggunakan air murni.

3. Tinggi bibit selada lebih tinggi bila menggunakan pupuk hantu dibandingkan dengan menggunakan air murni.

4. Waktu pindah tanam bibit selada lebih cepat dengan menggunakan pupuk hantu dibandingkan dengan menggunakan air murni

\section{Saran}

Benih selada yang akan disemai dianjurkan untuk direndam di dalam larutan yang mengandung pupuk hantu $0.2 \%$.

\section{DAFTAR PUSTAKA}

Anas. D. S, 2006. Buku Panduan Budidaya Tanaman Sayur. Bagian Produksi Tanaman. Departemen Agronomi dan Hortikultura IPB. Bogor.

Anonimous, 2009. Pupuk Hantu untuk Pertanian Organik. www.pencerah.com. 25 Januari 2010.

Anonimous, 2009. Budidaya Selada. www.Ipteknet.id. 25 Nopember 2009.

Fiona, 2009. Faktor yang mempengaruhi pertumbuhan tanaman.

www.fionaangelina.com. $\quad 28$ Juli 2008.

Kamil, J., 2005. Teknologi Benih I. Angkasa Raya Padang. Padang.

Mulyani, T., R.A.Bustami Rosadi, Ahmad Tusi, 2008. Pengaruh Media Tanam pada Sistem Irigasi Para terhadap
Pertumbuhan Tanaman

Selada (Lactuca sativa,L). Universitas Lampung.

Setyati, S.S, 2006. Zat Pengatur Tumbuh Tanaman.

Gramedia. Jakarta.

Surtinah, 2010. Agronomi Tanaman Budidaya. Alaf Riau. Pekanbaru.

Sutopo, L., 2004. Teknologi Benih. Fakultas Pertanian UNIBRAW. Rajawali Pers. Jakarta.

Pracaya 2007. Bertanam Sayuran Organik di Kebun, Pot, dan Polybag. Penebar Swadaya. Jakarta. 